Jurdimas (Jurnal Pengabdian Ke pada Masyarakat) Royal

Vol. 3 No. 2, Juli 2020, hlm. 169 - 174

DOI: https://doi.org/10.33330/jurdimas.v3i2.666

ISSN 2622-3813 (Online)

Available online at https://jurnal.stmikroyal.ac.id/index.php/jurdimas

\title{
EDUKASI PEMANFAATAN BULU-BABI (SEA URCHIN) MELALUI BUDI DAYA KERAMBA JARING APUNG
}

\author{
Alfi Sahri Remi Baruadi ${ }^{1}$, La Nane ${ }^{1 *}$ \\ ${ }^{1}$ Jurusan Manajemen Sumber Daya Perairan, Universitas Negeri Gorontalo \\ email: lanane@ung.ac.id
}

\begin{abstract}
Sea urchin is one of the fisheries resources products where its gonad can be consumed either in fresh or processed. Unfortunately, sea urchin has not been consumed due to society suspicion that may cause death if sea urchin gonad consumed. Thereby, we need to educate the society by instructing them in a participatory way on how to consume and cultivate sea urchin cultivation with a floating net cage. This work was conducted at Desa Lambangan Office (February 2020-March 2020) by involving 25 fishermen and 30 students from Gorontalo State University as the fellows of the society. The results of the counseling and practicing that conducted at desa Lambangan had been switched the paradigm of society that was formerly assuming sea urchin as a marine organism that has toxicity to be an organism that could be consumed and traded. Furthermore, the fishermen have overcome and able to handle how to build a floating net cage for the cultivation of sea urchins that they have learned in simulation on how to make floating net cage of sea urchins.
\end{abstract}

Keywords: sea urchin; counseling; floating net cage

\begin{abstract}
Abstrak: Bulu Babi (sea urchin) merupakan salah satu produk perikanan penting yang telurnya dapat dikonsumsi baik dalam keadaan segar maupun olahan. Sayangnya Bulu Babi belum dimanfaatkan karena dianggap beracun dan bila dikonsumsi dapat menimbulkan kematian. Karena itu, perlu dilakukan edukasi pada masyarakat melalui kegiatan penyuluhan bagaimana cara mengonsumsi dan membudidayakan Bulu Babi dengan sistem keramba jaring apung. Kegiatan ini dilaksanakan di desa Lambangan, kecamatan Pagimana, Sulawesi Tengah selama dua bulan (Februari 2020-Maret 2020 dengan melibatkan 25 masyarakat nelayan dan 30 mahasiswa Universitas Negeri Gorontalo sebagai pendamping masyarakat. Hasil dari kegiatan penyuluhan dan simulasi yang kami laksanakan telah mengubah paradigma masyarakat yang tadinya menganggap Bulu Babi sebagai biota laut beracun menjadi sesuatu yang dapat dikonsumsi dan dapat diperjualbelikan di pasar-pasar lokal. Selain itu, masyarakat juga telah menguasai dan mampu menerapkan konstruksi keramba budi daya Bulu Babi yang dilaksanakan melalui metode praktik simulasi pembuatan keramba jaring apung.
\end{abstract}

Kata kunci: Bulu Babi; penyuluhana; keramba jaring apung

\section{PENDAHULUAN}

Bulu Babi (sea urchin) yang juga dikenal dengan nama landak laut merupakan salah satu biota laut avertebrata pemakan tumbuhan atau herbivora (Suskiewicz \& Johnson, 2017) dari filum Echinodermata yang telurnya dapat dikonsumsi baik dalam keadaan segar (Nane, 2019a; Santos-Ferreira, 2020) maupun olahan (Nane, 2020). Telur Bulu Babi ini telah menjadi salah satu sumber daya perikanan komersial dunia (Bertocci, 2018) karena memiliki gizi 
Available online at https:/jurnal.stmikroyal.ac.id/index.php/jurdimas

yang baik dan diperdagangkan secara global. Di kepulauan Wakatobi, Sulawesi Tenggara, telur Bulu Babi umumnya diolah menjadi kukure dan menjadi penganan tradisional yang banyak diminati oleh masyarakat karena cita rasanya yang enak dan telah dikonsumsi sejak lama secara turun temurun (Nane, 2019b)

Telur Bulu Babi ini bahkan dianggap menjadi salah satu seafood mewah karena dirasa paling enak di dunia (Rubilar, 2016). (Takagi, 2018) mengungkapkan bahwa telur Bulu Babi memiliki cita rasa yang enak dan juga bernilai jual tinggi tergantung pada cita rasa, ukuran, dan teksturturnya. Faktor lain yang juga berpengaruh pada harga jual telur Bulu Babi dan permintaan pasarnya adalah warnanya (Vizzini, 2018). Karena itu, (Hadinoto, 2017) berpendapat kalau Bulu Babi sangatlah patut untuk dikembangkan menjadi sumber bahan pangan di Indonesia.

Dari sisi ekologi, Bulu Babi yang hidup di alam, ada yang hidup berkelompok dan ada juga yang hidup soliter (Lafarizi, 2020). Bulu Babi ini juga sebenarnya tersebar luas hampir di semua zona perairan laut (Saucède, 2015) baik pada laut dangkal maupun laut dalam (Ristanto, 2018). Adapun spesies Bulu Babi yang termasuk dalam kategori sebarannya ada pada perairan laut dangkal adalah Tripneustes gratilla, Diademe setosum, Mespilia globus dan Echinotrix diadema. Sementara itu, Bulu Babi yang sebarannya ada pada perairan laut dalam adalah Centrostephanus longispinus, Coelopleurus floridanus, Stylocidaris affinis, dan Cidaris cidaris (GonzálezIrusta, 2015). Bulu Babi secara umum juga dapat dijumpai pada ekosistem padang lamun (Sulistiawan, 2019), karang (Ling, 2018; Nane, 2020), dan ekosistem makroalga (Ling, 2015).

Pemanfaatan Bulu Babi utamanya dimaksudkan untuk tujuan konsumsi telurnya (Suriani, 2020) dan bukan untuk hiasan. Namun demikian, eksploitasi Bulu Babi untuk konsumsi di Kepualaun Wakatobi sudah cukup tinggi dan telah mengakibatkan penurunan stok Bulu Babi karena mengalami overfishing atau penangkapan berlebih (Nane \& Paramata, 2020). Namun demikian, (FAO, 2016) melaporkan bahwa tangkapan Bulu Babi untuk konsumsi telah menurun di seluruh dunia. Dari total tangkapan dari 108.969ton pada tahun 1995 menjadi 76.467 ton pada tahun 2014. Sayangnya, laporan penurunanan landak laut masih tetap terjadi seperti yang dilaporkan oleh (Parvez, 2016) tentang penurunan populasi Bulu Babi di Malaysia

Untungnya, penurunan stok Bulu Babi dunia saat ini juga turut disambut serius oleh para peneliti Bulu Babi dengan melakukan penelitian budi daya Bulu Babi (Ding, 2020) yang difokuskan pada pengembangan pakan untuk perbaikan kualitas telur (Takagi, 2018) serta peningkatan pertumbuhan larva dan juvenil Bulu Babi di hatchery tempat produksi pembesaran Bulu Babi (Sharp, 2018) untuk mengembalikan stok alam yang telah berkurang tersebut. Selain itu, dilakukan pula riset-riset tentang perbaikan cita rasa, warna telur, dan tekstur pada Bulu Babi dewasa (Volpe, 2018).

Sementara itu, di desa Lambangan, Kecamatan, Pagimana Sulawesi Tengah, stok Bulu Babi masih sangat melimpah karena belum dimanfaatkan baik untuk konsumsi maupun tujuan komersial. Hal ini dikarenakan oleh minimnya pengetahuan masyarakat setempat dalam mengelola Bulu Babi yang ada. Atas dasar permasalahan tersebut, dan mengingat Bulu Babi merupakan sumber daya yang sangat baik dan bernilai jual tinggi, maka perlu dilakukan kegiatan edukasi pada masyarakat di desa Lam- 
Available online at https:/jurnal.stmikroyal.ac.id/index.php/jurdimas

bangan sehingga potensi yang ada dapat dimanfaatkan semaksimal mungkin. Kami mencoba mengedukasi masyarakat melalui pendekatan partisipatif melalui kegiatan edukasi pembudidayaan Bulu Babi dengan system keramba jaring apung.

\section{METODE}

Kegiatan ini melibatkan 25 orang peserta dari masyarakat nelayan dan 30 orang mahasiswa dari Universitas Negeri Gorontalo sebagai tenaga pendamping lapangan selama dua bulan di Kantor desa Lambangan, kecamatan Pagimana, Sulawesi Tengah, Indonesia. Metode pelaksanaan kegiatan ini dalam bentuk Pelatihan, Metode ini dilakukan melalui kegiatan praktik tentang bagaimana cara memegang landak laut, dan cara menyiapkan keramba jaring apung untuk bulu babi. Kegiatan ini dilaksanakan dalam bentuk kegiatan praktik partisipatif. Dengan demikian, peserta dapat langsung bersentuhan dengan Bulu Babi yang tadinya dianggap beracun.

\section{PEMBAHASAN}

\section{Kegiatan Edukasi}

Edukasi yang telah dilaksanakan telah berhasil mengubah paradigma masyarakat yang selama ini takut pada Bulu Babi karena dianggap sebagai hewan beracun. Melalui penyuluhan (Gambar 1) tersebut, masyarakat mulai sadar karena adanya informasi dan pengetahuan serta skill yang pemateri transfer bahwa Bulu Babi merupakan potensi besar yang harus dimanfaatkan karena Bulu Babi merupakan komoditas ekspor. Adapun pendekatan yang dilakukan dalam proses edukasi ini adalah pendekatan partisipatif di mana transfer pengetahuan bukan saja sekadar teori tapi juga dengan cara praktik bagaimana menghadapi Bulu Babi dan memanfaatkannya. Metode ini cukup efektif dalam mempengaruhi dan menjegal pandangan-pandangan yang keliru perihal Bulu Babi yang dianggap beracun.

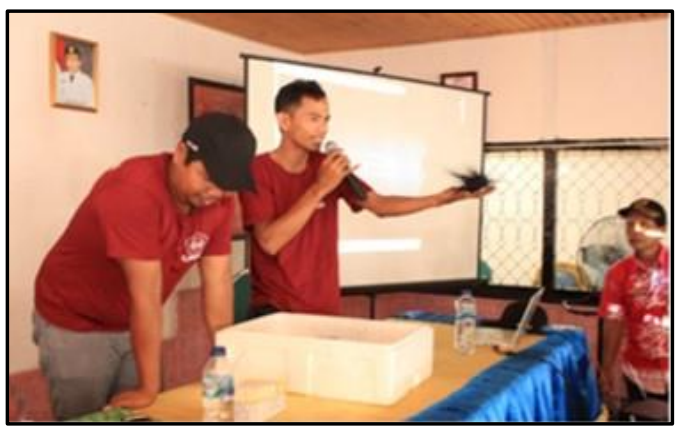

Gambar 1. Edukasi Bulu Babi

Bahkan di awal kegiatan, pesimisme warga terhadap potensi Bulu Babi sangat tinggi. Namun demikian sering dengan berjalannya acara dan proses transfer ilmu melalui contoh dan praktik. Segala pandangan negatif akan Bulu Babi yang beracun hilang dengan seketika.

\section{Kegiatan Simulasi KJA}

Selain proses edukasi yang dilakukan secara verbal (teori dan praktik) dalam pemanfaatan bulu babi. Dilakukan pula kegiatan transfer pengetahuan tentang pembuatan keramba jaring apung (Gambar 2).

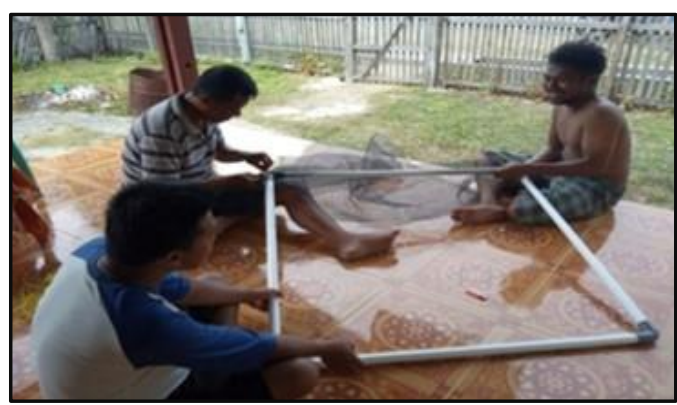

Gambar 2. Praktik Pembuatan KJA 
Hal ini dimaksudkan untuk lebih mendekatkan masyarakat dalam memanfaatkan potensi Bulu Babi yang ada. Melalui kegiatan ini, peserta dibekali dengan pengetahuan aplikatif dalam membuat KJA dimulai dari menyiapkan alat dan bahan, merancang KJA, hingga cara memasang KJA di lokasi pembudidayaan (Gambar 3).

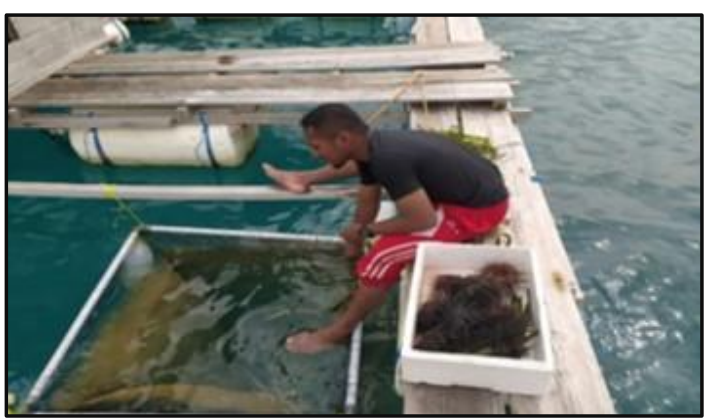

Gambar 3. Pemasangan KJA

Selain itu, masyarakat juga mengerti tentang mendesain dan teknik pemasangan KJA di lokasi. Termasuk pemilihan lokasi yang baik dan tepat dalam menempatkan keramba. Sehingga Bulu Babi yang dibudidayakan dapat berkembang dengan baik karena sesuai dengan faktor-faktor lingkungan yang mendukung. Termasuk ketersediaan pakannya.

\section{SIMPULAN}

Hasil Setelah terlaksananya kegiatan pengabdian ini, bahwa ada peningkatan pengetahuan masyarakat perihal pengelolaan perikanan Bulu Babi dan bagaimana cara mendesain konstruksi keramba jaring apung. Diharapkan kegiatan pembudidayaan dapat berkelanjutan dan dapat diaplikasikan oleh masyarakat secara kontinu. Sehingga potensi Bulu Babi yang melimpah dapat dimanfaatkan dengan baik untuk konsumsi dan juga meningkatkan ekonomi masyarakat setempat.

\section{DAFTAR PUSTAKA}

Bertocci, I., Blanco, A., Franco, J. N., Fernández-Boo, S., \& Arenas, F. (2018). Short-term variation of abundance of the purple sea urchin, Paracentrotus lividus (Lamarck, 1816), subject to harvesting in northern Portugal. Marine Environmental Research, 141, 247-254. https://doi.org/10.1016/j.marenvres. 2018.09.017

Ding, J., Zheng, D., Sun, J., Hu, F., Yu, Y., Zhao, C., \& Chang, Y. (2020). Effects of water temperature on survival, behaviors and growth of the sea urchin Mesocentrotus nudus: New insights into the stock enhancement. Aquaculture, 519, 734873.

https://doi.org/10.1016/j.aquacultur e. 2019.734873

FAO. (2016). Global production statistics 1950-2014. Available at: http $/ /$ www.fao.org/figis/servlet/Ta bSelector.

González-Irusta, J. M., González-Porto, M., Sarralde, R., Arrese, B., Almón, B., \& Martín-Sosa, P. (2015). Comparing species distribution models: A case study of four deep sea urchin species. Hydrobiologia, 745(1), 43-57. https://doi.org/10.1007/s10750014-2090-3

Hadinoto, S., Sukaryono, I. D., \& Siahay, Y. (2017). Kandungan gizi gonad dan aktifitas antibakteri ekstrak cangkang Bulu Babi (Diadema setosum). Jurnal Pascapanen Dan Bioteknologi Kelautan Dan Perikanan, 12(1). https://doi.org/10.15578/jpbkp.v12i 1.281 
Available online at https:/jurnal.stmikroyal.ac.id/index.php/jurdimas

Lafarizi, A. (2020). Struktur Populasi Anggota Kelas Bulu Babi (Echinoidea) di Zona Intertidal Pantai Batu Lawang Taman Nasional Alas Purwo. Repository Unej. https $/ /$ repository.unej.ac.id/handle/ $123456789 / 82593$

Ling, S. D., Barrett, N. S., \& Edgar, G. J. (2018). Facilitation of Australia's southernmost reef-building coral by sea urchin herbivory. Coral Reefs, 37(4), 1053-1073. https //doi.org/10.1007/s00338018-1728-4

Ling, S. D., Scheibling, R. E., Rassweiler, A., Johnson, C. R., Shears, N., Connell, S. D., Salomon, A. K., Norderhaug, K. M., Pérez-Matus, A., Hernández, J. C., Clemente, S., Blamey, L. K., Hereu, B., Ballesteros, E., Sala, E., Garrabou, J., Cebrian, E., Zabala, M., Fujita, D., \& Johnson, L. E. (2015). Global regime shift dynamics of catastrophic sea urchin overgrazing. Philosophical Transactions of the Royal Society B: Biological Sciences, 370(1659), 20130269.

https $/ /$ doi.org/10.1098/rstb.2013.02 69

Nane, L. (2019a). Efisiensi Mesin Teknologi Sapurata Dalam Mengoptimalisasi Produksi Inovasi Pangan Kukure Di Pulau Barrang Lompo, Makassar. https//doi.org/10.31230/osf.io/q8sp $\mathrm{g}$

Nane, L. (2019b). Studi Keberlanjutan Perikanan Landak Laut Berdasarkan Dimensi Biologi, Ekologi Dan Teknologi Di Sekitar Pulau Tolandono Dan Pulausawa Kawasan Konservasi Wakatobi [Skripsi, Universitas Hasanuddin]. https $/ /$ Marxiv.Org/9zdvr/
Nane, L. (2020). Pemanfaatan Telur Landak Laut Diadema setosum di Pulau Taliabu, Maluku Utara, Indonesia.

https://doi.org/10.31219/osf.io/kmt uv

Nane, L., Baruadi, A. S. R., \& Mardin, H. (2020). Density of the blueblack urchin Echinotrix diadema (Linnaeus, 1758) in Tomini Bay, Indonesia. Tomini Journal of Aquatic Science, 1(1), 16-21. https://doi.org/10.37905/tjas.v1i1.5 939

Nane, L., \& Paramata, A. R. (2020). Impact of Overfishing on Density and Test-Diameter Size of the Sea Urchin Tripneustes gratilla at Wakatobi Archipelago, South-Eastern Sulawesi, Indonesia. ILMU KELAUTAN: Indonesian Journal of Marine Sciences, 25(2), 53-56. https://doi.org/10.14710/ik.ijms.25. 2.53-56

Parvez, M. S., Rahman, M. A., \& Yusoff, F. M. (2016). Sea Urchin Fisheries in Malaysia: Status, Potentials and Benefits. International Journal of Chemical, Environmental \& Biological Sciences (IJCEBS), 4(1), 64-66.

Ristanto, A., Yanti, A. H., \& Setyawati, T. R. (2018). Sea Urchin (Echinoidea) Distribution and Abundance in the Intertidal Zone of Bengkayang Regency. Biosaintifika: Journal of Biology \& Biology Education, 10(1), 32-40. https://doi.org/10.15294/biosaintifi ka.v10i1.9763

Rubilar, T., Epherra, L., Deias-Spreng, J., Vivar, M. E. D. D., Avaro, M., Lawrence, A. L., \& Lawrence, J. M. (2016). Ingestion, Absorption and Assimilation Efficiencies, and Production in the Sea Urchin Arba- 
cia dufresnii Fed a Formulated Feed. Journal of Shellfish Research, 35(4), 1083-1093. https $/ /$ doi.org/10.2983/035.035.043 1

Santos-Ferreira, N., Mesquita, J. R., Rivadulla, E., Inácio, Â. S., Nascimento, M. S. J., Romalde, J., \& Martins da Costa, P. (2020). Norovirus contamination of sea urchins (Paracentrotus lividus): Potential food risk for consumers. Food Control, 111, 107041. https:/doi.org/10.1016/j.foodcont.2 019.107041

Saucède, T., Díaz, A., Pierrat, B., Sellanes, J., David, B., Féral, J.-P., \& Poulin, E. (2015). The phylogenetic position and taxonomic status of Sterechinus bernasconiae Larrain, 1975 (Echinodermata, Echinoidea), an enigmatic Chilean sea urchin. Polar Biology, 38(8), 1223-1237. https $/ /$ doi.org/10.1007/s00300015-1689-9

Sharp, W. C., Delgado, G. A., Hart, J. E., \& Hunt, J. H. (2018). Comparing the behavior and morphology of wild-collected and hatcherypropagated long-spined urchins ( Diadema antillarum ): Implications for coral reef ecosystem restoration. Bulletin of Marine Science, 94(1), 103-122.

https//doi.org/10.5343/bms.2017.1 068

Sulistiawan, R., Solichin, A., \& Rahman, A. (2019). The Correlation of Seagrass Density with Abundance of Sea Urchins (Echinoidea) in Pancuran Beach Karimunjawa National Park, Jepara. Journal of Marquares, 8(1), 28-36.
Suriani, S., Latumahina, B. M., Hitalessy, R. B., \& Eddy, L. (2020). Hubungan Populasi Makroalga (Padina sp) dengan Bulu Babi (Tripneustes gratilla) di Perairan Pantai Desa Titawaai Kabupaten Maluku Tengah. Jurnal Riset Perikanan dan Kelautan, 2(1), 165-175.

Suskiewicz, T. S., \& Johnson, L. E. (2017). Consumption rates of a key marine herbivore: A review of the extrinsic and intrinsic control of feeding in the green sea urchin. Marine Biology, 164(6), 131. https://doi.org/10.1007/s00227017-3159-0

Takagi, S., Murata, Y., Inomata, E., Endo, H., Aoki, M. N., \& Agatsuma, Y. (2018a). Dietary Effect of Kelp (Saccharina japonica) on Gonad Quantity and Quality in Sea Urchins ( Mesocentrotus nudus ) Collected from a Barren Before the Fishing Season. Journal of Shellfish Research, 37(3), 659-669. https://doi.org/10.2983/035.037.031 8

Vizzini, S., Visconti, G., Vaccaro, A., \& Mazzola, A. (2018). Experimental rearing of the sea urchin Paracentrotus lividus fed with discards of the lettuce Lactuca sativa in a seabased system. Aquaculture Research, 49(2), 631-636. https://doi.org/10.1111/are.13492

Volpe, M. G., Fabbrocini, A., Siano, F., Coccia, E., Scordella, G., Licchelli, C., De Sio, F., \& Paolucci, M. (2018). Gonad quality of sea urchin Paracentrotus lividus cultured in an offshore pilot-scale trial on the south-east Italian coast. Aquaculture Nutrition, 24(5), 1444-1455. 